Length of Residence in Country.-Two years 6 months.

Number of Attack and Date of Present Attack.-First, November 27 th, 1897. Result, Duration of

Remarks.-Took calomel antipyrin, $20 \mathrm{grs}$. (in two doses), prior to onset of hæmoglobinuria; vomiting slight; bowels constipated; severe pyrexia

\section{CASE v.}

R. S., aged 25, Indian sepoy, Fort Johnston.

Length of Residence in Country.-Three years 3 months.

Number of Attack and Date of Present Attack.-First, February $23 \mathrm{r}^{\mathrm{d}}$. 1808.

Urine: Duration:of Hæmoglobinuria.-Fifty-eight hours ; urine abundant. Result.-Recovery.

Remarks.-Returning from expedition to Mpeseni's country; has suffered a good deal from fever lately; severe vomiting, and frequent calls to stool nourished four entire days by nutrient enemata; treated with hypodermic injections of hydrobromate of quinine; made a slow recovery.

\section{Case vi.}

J. G., aged 24, engineer, trading company, Lake N yassa.

Cength of Residence in Country.-One year ir months.

Number of Attack and Date of Present Attack.-First, April 8tlı, 1808.

Urine: Duration of Hæmoglobinuria.-Fifty-four hours; urine abundant. Result.-Recovery.

Remarks. - Has had good health except when temporarily employed on the Upper Shiré, when present attack occurred. Temperature on admission, ro5.2 ; incessant vomiting; bowels constipated. Blood : No paraquinine. Made a slow recovery.

$$
\text { CASE viI. }
$$

W H., aged 25, engineer, trading company, Upper Shiré, Fort Johnston and Lewonde Districts.

Length of Residence in Country.-Two years 6 months.
Number of Attack and Date of Present Attack. - First, May 8th, $x 898$.

Urine: Duration of Hæmoglobinuria.-Thirty hours ; urine suppressed.

Result,-Death.

Remarks.-Has suffered from constant attacks of fever ; is very anæmic and emaciated; heart dilated : hæmoglobinuria preceded by fever of two days' duration. Took antipyrin and quinine. Prior to onset of hæmoglobinuria several attacks of shivering and lumbar pain; at night temperature ro $5^{\circ}$ : passed bloody urine at 5 A.M. ; first seen at ro A.M. : temperature constant vomiting of greenish-yellow bile. On the second day urine diminished in quantity, and altogether only about 8 ounces were passed; vomiting severe and persistent, eausing patient much distress on the third day about ro ounces of urine passed, of a dirty brown colour, and loaded with sediment. Patient suddenly, of a dirty brown colour, and collapse; temperature $95.4^{\circ}$; hot bottles to feet and abdomen, hypodermic injection of digitalin and strychnine. Temperature rose to $96.8^{\circ}$, and was passed, but a few drachms were with difficulty drawn off by means of a catheter; vomiting could not be checked, and all nourishment was given by enema. On the fifth day an obstinate hiccough developed, which persisted throughout the night and the following morning, when the patient died in a state of collapse. Treated with quinine by mouth and
hypodermically.

$$
\text { CASE VIII. }
$$

J. C., aged 32, boatswain, B.C.C.A., Upper Shiré.

Length of Residence in Country.--Nine months.

Number of Attack and Date of Present Attack-First. July ${ }_{3}$ rd, 1898.

Urine: Ditration of Hæmoglobinuria.-Thirty-two hours ; urine suppressed. Result.-Death.

Remarks. - Has constantly been on sick list since arrival in the country; moderate drinker, but drinking heavily prior to attack; sent up by Ir. G. from Mpimbi to Fort Johnston for treatment, with a note that for past two days no urine had been passed. On admission about an ounce of urine was passed with difficulty ; was of a chocolate colour and thick consistence. On the sixth day of illness patient had frequent attacks o epistaxis from both the anterior and posterior nares; no urine was passed. On the seventh day skin hot and dry, and patient drowsy, with slight muscular twitchings. As no urine had been passed, $\frac{1}{8} \mathrm{gr}$. of pilocarpin injected, followed by profuse sweating. On the eighth day patient rad three attacks of syncope ; digita of syncope at ${ }^{*}$ P.M., to which he succumbed; treated with quinine.

W. W., aged 35 , tradesman's assistant, Fort Johnston.

Length of Residence in Country.-Four months.

Number of Attack and Date of Present Attack. - First, July 2oth, I899.

Urine: Duration of Hæmoglobinuria.-Sixty hours; urine moderate.

Result.-Recovery.

Remarks.-Prior to arrival in British Central Africa has been at Salisbury, Tete, and Blantyre, at all which places has suffered from malaria fever. Is very anæmic ; liver dulness normal: spleen slightly enlarged, but not tender. Present attack commenced with an ill-defined rigor and bilious vomiting; before the development of hæmoglobinuria Dr. D. made an examination of the blood, and found parasites of malignant tertian infection: thereafter, no parasites. Placed immediately on a mixture of sodii bicarb. gr.x and liq. hydrarg. perchlor. mxxx, given every two hours during first day, and every three hours on following days. Corpuscle estimation: second day, $3 \frac{3}{4}$ millions: third day, about 2 millions. The corpuscles were "brassy" in appearance, some shrunken, others pale and swollen; urin

T. R., aged 32 , naval officer, Fort Johnston.

Number of Attack and Date of Present Attack.-Third (?), November ${ }_{3}$ rd,

rogo:

Urine: Duration of Hæmoglobinuria.-Sixty-two hours ; urine ahundant. Result.-Recovery.
Remarks.-Suffering from mercurial ptyalism at time of attack. Hæmoglobinuria preceded by a distinct rigor and pains in the limbs. Temperature ro4. $8^{\circ}$. Bilious vomiting; bowels constipated : placed on same mixture as previous case ; made a good recovery. N.B.- Urine cleared globinuric, and remained so for about 8 hours.

\section{CASE XI.}

C. S., aged 4o, Indian sepoy, Fort Johnston.

Length of Residence in Country.-One year.

Number of Attack and Date of Present Attack.-First, November $22 n d, ?_{1} 89$

Urine: Duration of Hæmoglobinuria.-Sixty-eight hours ; urine moderate. Result.-Recovery.

Remarks.-Has suffered from malarial fever in India, and has had three or four attacks since arrival in this country. Vomiting severe and persistent Patient is anæmic and emaciated. Liver slightly enlarged; owing to patient's exhausted condition.

CASE XII.

L. O., aged 23, tradesman's assistant, Fort Johnston.

Length of Residence in Country.-One year ro months.

Number of Attack and Date of Present Attack.-Second, March 7 th, r9oo.

Urine: Duration of Hæmoglobinuria.-Sixty hours; urine abundant.

Result.-Recovery.

Remarks.-First attack after 8 months' residence at Kota-Kota on Lake Shiré; has had a moderate amount of fever since; is very anæmic ; liver and spleen normal ; had been feverish for two days prior to development of present attack, during which time he had taken about 20 grs. of quinine per diem ; placed on same mixture as the preceding cases. On the eighth day of illuess 5 grs. of quinine were given in the morning, and 5.s. at noon. At 4 P.M. the patient again passed hæmoglobinuric urine. The quinine was discontinued, and the urine cleared in the course of a
few lours. Recovery was retarded owing to persistent pyrexia, the temperature frequently rising beyond ro $5^{\circ}$.

J. C. B., aged 25, agent, trading company, Fort Johnston.

Length of Residence in Country.-Four years ro months.

Number of Attack and Date of Present Attack. - First, April r 3 th, 1900

Urine: Duration of Hæmoglobinuria.-Sixty-four hours ; urine abundant. Result.-Recovery.

Remarks.- Has resided mainly in the Shiré Highlands, and has had good health; developed present attack on arrival on the Upper Shiré; vomiting
slight; treated with same mixture as preceding cases. Made a good recovery.

W. S., aged 32, planter, Zomba.

CASE XIV.

Length of Residence in Country.-Two years.

Number of Attack and Date of Present Attack.-Second, June 24th, rgoo.

Urine: Duration of Hæmoglobinuria.-Sixty hours; urine abundant.

Result.-Recovery.

Remarks.-First attack six months previously; little or no vomiting. Placed on mixture as previous case. Made a good recovery.

E. D., aged 29, transport work, Blantyre.

Length of Residence in Country.-Two years 9 months.

Number of Attack and Date of Present Attack. - Second, October 2nd, r9oo.

Urine: Duration.of Hæmoglobinuria.-Fifty-four hours; urine moderate. Result.-Recovery

Remarks.-First attack nine months previously. Present attack preceded by an ill-defined rigor and bilious vomiting. Took ro grs. quinine in the evening; noticed black-water symptoms the following morning; persistent vomiting on admission; bowels constipated. Placed on the same mixture as preceding cases. Made a good recovery, but during convalescen
to ro $3^{\circ} \mathrm{F}$.

\section{NOTE ON THE STAINING OF FLAGELLA.}

\section{By J. BLACKBURN SMITH, B.A., M.B.,} Captain I.M.S.

[From the Pathological Laboratory, Queen's College, Belfast.]

IT has been pointed out that the difficulty of discovering any single reliable method of staining the flagella of all kinds of bacteria probably means that for each species a special method is required. It is found in practice that a method which gives good results with one species will often fail to do so with another.

One of the best and easiest methods for general use is that introduced by Pitfield, and in working at the application of this method to the staining of the flagella of the typhoid bacillus, I found the modification now described more reliable than any given in the textbooks, and also very easily carried out. The mordant is made in the following manner: A saturated solution of perchloride of mercury made by boiling, is poured while still hot into a bottle in which crystals of ammonia alum have been placed in quantity more than sufficient to saturate the fluid. The bottle is well shaken and then allowed to cool. In Richard Muir's modification of Pitfield's method, saturated solutions of ammonia alum mordant. The method I have given provides a fluid saturated with both salts.

To ro c.cm. of this 'fluid ro c.cm. of a freshly-made ro per cent. solution of tannic acid are added, and 5 c.cm. of carbol fuchsin. These are mixed 
and filtered. This mordant will keep for a considerable period of time. The cover glasses are prepared by washing them in a strong solution of hydrochloric acid. They are taken from the acid, wiped with a clean cloth, and thoroughly heated over a bunsen flame. $A$ convenient way of doing this is to place them on a slide upon a tripod, and apply the flame. On a cover glass which has been sufficiently heated, the film spreads witl perfect evenness. The traces of acid which are left on the glass make it easier to avoid subsequent precipitation of mordant or stain. The bacill are placed on the cover slip and fixed. The mordant is then filtered, poured on the preparation, and heated till steam is given off. Boiling should be avoided, as it leads to precipitation. The preparation should distill at this temperature for three minutes. It is then well washed in distilled water, and the stain is added, and heated in the same way for three or four minutes.

The stain is made by adding r c.cm. of a saturated alcoholic solution of entian violet to ro c.em. of a saturated solution of ammonia alum. This

filtered and poured on the preparation.

This method can be applied generally. I have found it parrticularly applicable to bacilli of the typhoid and $B$. coli group. It has been used in the laboratory also for the staining of the flagella of B. choleræ asiat., B. tetani, V. aquatilis, etc. The flagella are clearly defined and of moderate thickness. The advantage of the method is the certainty and rapidity with which results are obtained. Anyone who carries out the instructions given above will after a very little experience obtain without fail successful preparations.

\section{THE PROPHYLACTIC AND CURATIVE TREATMENT OF PLAgUE.}

A. LUSTIG,

Professor of Pathology, Royal

and

University, Florence.
G. GALEOTTI, University, Cagliari.
Professor of Pathology. Royal

Among the numerous articles dealing with plague which were published in the Plague Number of the BRITISH Medical Journal, there was one by C. Balfour Stewart, which has induced us to make some observations as to the curative serum and the prophylactic prepared by our method. At the same time we would take the opportunity of describing some of the most recent results, which, although published in the writings of Dr. Choksey, Dr. Polverini, and Dr. Mayr, seem not to be well known by some of those who take an interest in the questions concerning the plague.

The observations have reference to the theoretical side of the question, while some rectifications are necessary as regards to the statements concerning the different results obtained, which Balfour Stewart does not seem to be well acquainted with.

The Preparation of the Prophylactic.

According to our method this is based on the following principle: to inoculate, as a preventive medium, the substance which is alone able to cause in the organism treated an active immunity produced by the action of a specific bactericidal power. This we obtained by isolating from the microbes the nucleo-proteid of which they are partly composed, for it is to this that immunity is due, although it can be also produced by injecting entire cultures of plague microbes.

\section{Haffinine's Method.}

This method, however, has numerous drawbacks, as to which we would refer to a previous paper of ours in this Jodrnal. Haffkine's prophylactic. certainly cannot, as Balfour Stewart suggests, be called the greatest success as a scientific preparation, because it is not possible to establish any qualitative and quantitative relation between the substances contained in that prophylactic and the degree of immunity which is derived from it; while its practical results are still far from those which are looked for in a thorough immunisation, as, for example, had been obtained for small-pox.

The Preparation of the Curative Serum.

As the above-mentioned nucleo-proteid is the only substance capable of determining a specific bactericidal power in animals treated, we use the serum of such animals (after a sufficient treatment) as a curative medium. The question of the existence of specific extracellular toxins produced by the plague microbes is still very much debated. The question of the antitoxic capacity of the serum is even more uncertain; as nobody has yet succeeded in obtaining an antitoxic serum by means of the injection of filtered cultures deprived also of those toxic elements which constitute the protoplasm of the bacterial cells.

Through the injection of this nucleo-proteid, which is an intracellular specific poison, we confer on the serum of the animals treated with it a bactericidal power, and very likely an antitoxic one against the same. Balfour's assertion that "a horse treated with a nucleo-proteid extracted from the dead microbes would be immunised with even less efficiency than one treated with the killed microbes together with their metabolic products" is theoretically unfounded, and as it does not spring from any principle of experience and practically is not true, for the results obtained from our serum are far better than those given by other serums experimented. in India.

History of the Experiments with the Curative Serum. The first serum was obtained in the year 1897 from an immunised horse in the Laboratory of Pathology in Florence, and was tried in India on 6 patients at the Arthur Road Hospital, 5 of whom recovered. Besides 29 patients were treated with it in the Poona Plague Hospital, and 21 of them got well. In the year 1898 the Municipal Corporation asked us to prepare a certain quantity of serum which was chiefly used at the Arthur Road Hospital. The clinical observations concerning the effects of this serum have been collected with the assistance of Dr. Choksey, in charge of the above-mentioned hospital, in the most careful way. We injected the serum. into every individual infected with plague, without distinction of age or period of illness, making no account of the complications present, and it was even injected into some dying persons. It is besides worthy of remark that Arthur Road Hospital receives all patients, belonging to the lowest class of people, poor, ill-fed, and in consequence little able to resist the infection which in these conditions appears in the most dangerous form.

The number of patients treated with our serum on June Ioth was 175. We made the injections under the skin of the arm or the thigh, using Roux's syringe. The results were altogether very satisfactory, but we noted a great difference in the serums coming from different horses. Thus, the serum obtained from the horse marked No. $I$ in the following table has always given the same effects, in spite of its being extracted at different times and used for different patients. The results obtained with this horse were not very good, and lowered the proportion of our recoveries; while the serum obtained from horse No. 4 has been most efficacious in all cases.

Results obtained with Different Serums.

\begin{tabular}{|c|c|c|c|c|c|}
\hline $\begin{array}{l}\text { No. of } \\
\text { Horse. }\end{array}$ & $\begin{array}{l}\text { No. of Times } \\
\text { Bled. }\end{array}$ & $\begin{array}{c}\text { No. of Pa- } \\
\text { tients Treated. }\end{array}$ & $\begin{array}{l}\text { No. of } \\
\text { Deaths. }\end{array}$ & $\begin{array}{l}\text { No. of } \\
\text { Recoveries. }\end{array}$ & $\begin{array}{l}\text { Percentage of } \\
\text { Recovery. }\end{array}$ \\
\hline \multirow[t]{2}{*}{ I } & $\begin{array}{l}1 \\
2 \\
3\end{array}$ & $\begin{array}{r}24 \\
4 I \\
6\end{array}$ & $\begin{array}{r}18 \\
30 \\
5\end{array}$ & $\begin{array}{r}6 \\
\mathrm{II} \\
\mathrm{I}\end{array}$ & \\
\hline & & 71 & 53 & 18 & 25.35 \\
\hline \multirow[t]{2}{*}{ II } & $\begin{array}{l}1 \\
2 \\
3\end{array}$ & $\begin{array}{l}- \\
1_{3} \\
17\end{array}$ & $\bar{z}$ & 二 & $\cdots$ \\
\hline & | & 30 & 14 & 16 & $53 \cdot 33$ \\
\hline \multirow[t]{2}{*}{ III } & $\begin{array}{l}\mathbf{I} \\
2 \\
3\end{array}$ & $\begin{array}{l}19 \\
24 \\
\text { II }\end{array}$ & $\begin{array}{r}10 \\
12 \\
3\end{array}$ & $\begin{array}{r}9 \\
12 \\
8\end{array}$ & \\
\hline & $i$ & 54 & 25 & 29 & 53.70 \\
\hline \multirow[t]{3}{*}{ IV } & $\begin{array}{l}\mathbf{I} \\
2\end{array}$ & $\begin{array}{r}8 \\
12\end{array}$ & $\begin{array}{l}3 \\
5\end{array}$ & $\begin{array}{l}5 \\
7\end{array}$ & . \\
\hline & 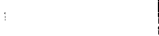 & 20 & 8 & 12 & 60.00 \\
\hline & i & 175 & ICO & 75 & 42.70 \\
\hline
\end{tabular}

Of the 175 patients treated with the serum, 18 were in a most dangerous state when they were put under treatment. These patients had received only one or two injections before they died.

Thus, as Dr. Choksey has rightly considered, these 18 cases 